\title{
Alkaloids: Therapeutic Potential against Human Coronaviruses
}

\author{
Burtram C. Fielding ${ }^{1,+}{ }^{\mathbb{D}}$, Carlos da Silva Maia Bezerra Filho ${ }^{2} \mathbb{D}$, Nasser S. M. Ismail ${ }^{3}$ and $^{-}$ \\ Damião Pergentino de Sousa $2, *,+\mathbb{D}$
}

1 Molecular Biology and Virology Research Laboratory, Department of Medical Biosciences, University of the Western Cape, Bellville 7535, South Africa; bfielding@uwc.ac.za

2 Department of Pharmaceutical Sciences, Federal University of Paraíba, Paraíba 58051-900, Brazil; carlosmaia1996@gmail.com

3 Pharmaceutical Chemistry Department, Faculty of Pharmaceutical Sciences and Pharmaceutical Industries, Future University in Egypt, Cairo 12311, Egypt; saadnasser2003@yahoo.com

* Correspondence: damiao_desousa@yahoo.com.br; Tel.: +55-833-216-7347

+ These authors contributed equally to this work.

Academic Editor: Maria José U. Ferreira

Received: 30 September 2020; Accepted: 10 November 2020; Published: 24 November 2020

\begin{abstract}
Alkaloids are a class of natural products known to have wide pharmacological activity and have great potential for the development of new drugs to treat a wide array of pathologies. Some alkaloids have antiviral activity and/or have been used as prototypes in the development of synthetic antiviral drugs. In this study, eleven anti-coronavirus alkaloids were identified from the scientific literature and their potential therapeutic value against severe acute respiratory syndrome coronavirus-2 (SARS-CoV-2) is discussed. In this study, in silico studies showed an affinity of the alkaloids for binding to the receptor-binding domain of the SARS-CoV-2 spike protein, putatively preventing it from binding to the host cell. Lastly, several mechanisms for the known anti-coronavirus activity of alkaloids were discussed, showing that the alkaloids are interesting compounds with potential use as bioactive agents against SARS-CoV-2.
\end{abstract}

Keywords: COVID-19; natural products; antiviral drug; SARS-CoV; MERS-CoV; coronaviruses; virus; SARS-CoV-2

\section{Introduction}

Current drug recommendations for the treatment of coronavirus disease-2019 (COVID-19) are based on historical reports from various severe acute respiratory syndrome coronavirus (SARS-CoV) and Middle Eastern respiratory syndrome coronavirus (MERS-CoV) studies [1]. Some evidence from these studies suggests that the use of an integrative approach, such as the use of western medicine with herbal medicines and/or medicinal plant-based natural compounds, is more effective in controlling the coronavirus infection and in reducing the number of deaths [2]. Also, the use of effective combinational therapy could reduce the effective concentration of compounds below the therapeutic plasma concentrations, providing better clinical benefits [3].

Alkaloids are a class of naturally occurring nitrogen-containing compounds that have at least one nitrogen as a heteroatom, usually in a heterocyclic ring-with basic properties-and produce pronounced physiological responses. According to the biosynthetic pathway, alkaloids can be classified into, (1) true alkaloids that originate from amino acids and contain a nitrogen-based heterocyclic ring; (2) proto-alkaloids that also derive from amino acids, but do not contain a nitrogen moiety in a heterocyclic system; (3) pseudoalkaloids that do not originate from amino acids. Currently, more than 8000 natural compounds are classified as alkaloids [4,5]. 
Alkaloids are widely distributed in the plant kingdom, with some estimates that $25 \%$ of Gymnosperms and Angiosperms produce these metabolites. Moreover, alkaloids are present in plants from the families, Apocynaceae [6], Asteraceae [7], Papaveraceae [8], Rutaceae [9], Solanaceae [10], Erythroxylaceae [11], ans Fabaceae [12] among others.

Since the discovery of this class of natural products, several biological activities associated with alkaloids have been reported, including analgesic [13], antibacterial [14], antifungal [15], anti-inflammatory [16], anticancer [17], and antiviral [18] activity. Among the alkaloids that have antiviral activity, berberine has shown activity against the chikungunya virus, human cytomegalovirus (HCMV), and hepatitis C virus (HCV) [19-21], tomatidine against dengue virus (DV) [22], michellamine $B$ against human immunodeficiency virus (HIV) [23], oxymatrine against influenza A virus [24], and palmatine against zika virus (ZV) [25]. In addition, plants rich in alkaloids also show antiviral action, such as the seeds of Peganum harmala L. that can inhibit influenza A virus [26] and root tubers of Stephania cepharantha Hayata that improve the survival of mice infected by herpes simplex virus type 1 (HSV1) [27].

Therefore, considering the therapeutic anti-viral potential, including anti-coronaviral, of this class of natural products, the aim of this study was to review the antiviral activity of alkaloids against coronaviruses. This study looked at the various alkaloids which showed in vitro and in vivo anti-coronavirus activity, with emphasis on human anti-coronaviral activity. In silico analysis was then performed to study the affinity of the eleven identified alkaloids — with anti-coronavirus activity-for binding to the receptor-binding domain of SARS-CoV-2 spike protein.

\section{Results}

In recent times, natural alkaloids and alkaloid analogs have been studied extensively for their potent antioxidant and anti-inflammatory [28], as well as broad anti-viral properties [29]. In particular, with the current coronavirus pandemic in mind, alkaloids provide a rich source of important chemical compounds with great potential as novel anti-coronavirus agents (Figure 1) [30,31].

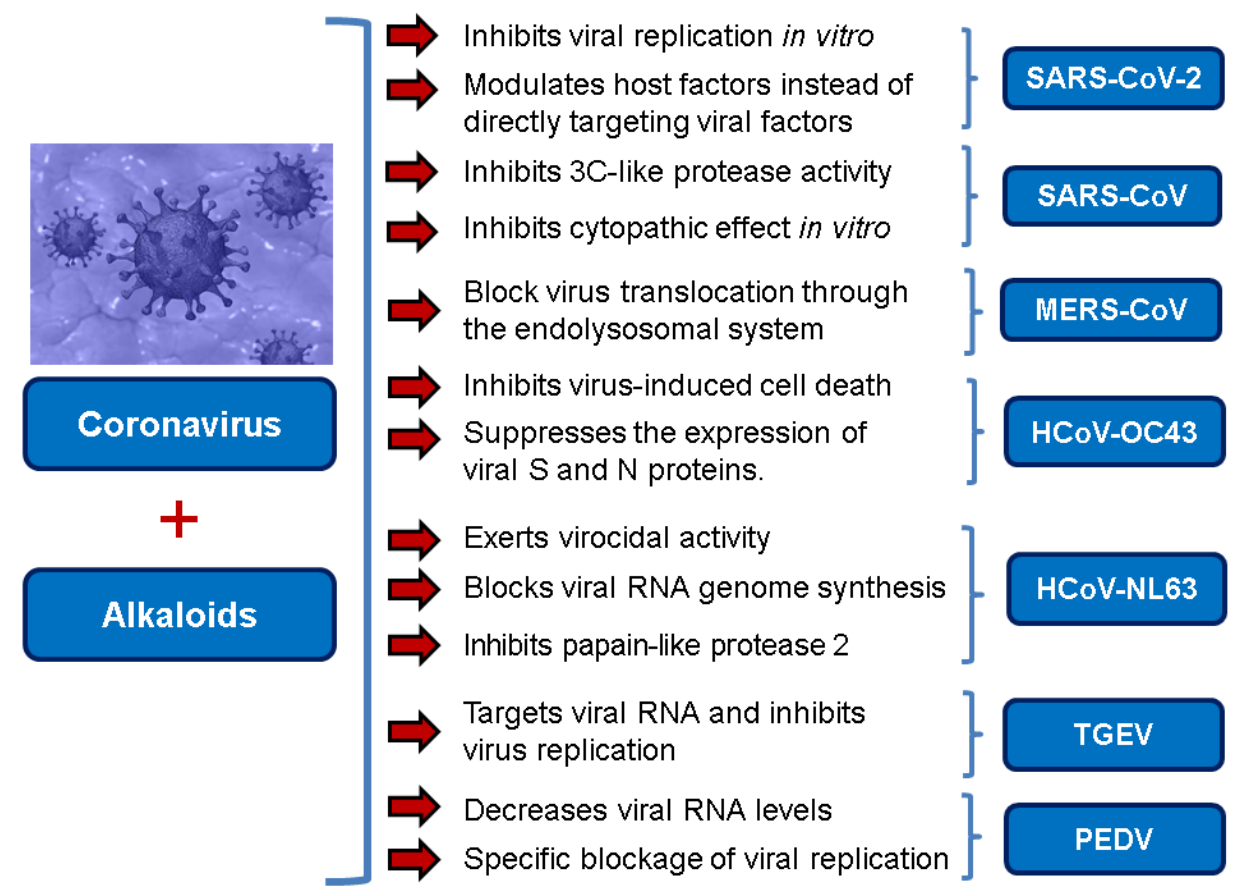

Figure 1. Main inhibitory actions of alkaloids against coronaviruses.

Homoharringtonine (HHT) is a plant-derived alkaloid extracted from some species of the Cephalotaxus genus [32,33]. HHT exhibits antiviral activity against a diverse range of viruses, including 
the varicella-zoster virus (VZV) [34], hepatitis B virus (HBV) [35], human echovirus 1 (HEV1) [36], vesicular stomatitis virus (VSV), Newcastle disease virus (NDV), and HSV1 [37] among others. Moreover, groups have reported that HHT shows strong anti-viral activity against diverse human and animal coronaviruses [37,38]. In a screen of 727 compounds in the NIH Clinical Collection small molecule database, HHT-with the lowest $\mathrm{IC}_{50}$ of the 84 compounds identified-was identified as the strongest inhibitor against various coronaviruses. In this study, HHT effectively inhibited coronavirus infection (a reduction in virus titer of $\geq 8 \log _{10}$ ) by interfering with the coronavirus replication. The authors reported an $\mathrm{IC}_{50}$ of about $0.011 \mu \mathrm{M}$ with a dose-dependent effect on virus inhibition [38]. In a later study by Dong and colleagues (2018), HHT was shown to effectively reduce porcine epidemic diarrhea virus (PEDV) viral load in infected cells and animals. The alkaloid was reported to provide optimal inhibitory activity, without death, at a dose of $0.05 \mathrm{mg} / \mathrm{kg}$ in piglets. Interestingly, HHT treatment effectively decreases mRNA levels of PEDV nucleocapsid in pig intestine and blood, indicating efficient inhibition of PEDV replication in vivo. Moreover, HHT-dosed piglets did not show a pathological change in tissues or symptoms of diarrhea and cachexia [37]. In a very recent study, HHT was reported to inhibit the in vitro replication of SARS-CoV-2. In Vero E6 cells, the alkaloid was reported to have a $\mathrm{CC}_{50}$ of $59.75 \mu \mathrm{M}$, and an $\mathrm{EC}_{50}$ of 2.55 and $2.14 \mu \mathrm{M}$ for the reduction in infectious virus and reduction in viral RNA copy numbers, respectively [3]. The authors do not speculate on the mode of HHT action but it has previously been reported to be a protein synthesis inhibitor [33], so this might provide clues for future studies on the mode of action.

Lycorine is one of the major alkaloids isolated from the plant Lycoris radiate, a traditional Chinese medicinal herb [39]. This alkaloid possesses many diverse biological functions, including antiviral [39] and anti-inflammatory properties [40]. Lycorine has been reported to have antiviral action against many diverse viruses, including DV [41], ZV [42], poliovirus [43], HCV [44], enterovirus 71 (EV-71) and coxsackievirus A16 [45,46], avian influenza H5N1 virus [47], HSV1 [48], and bunyaviruses and Rift Valley fever virus (RVFV) [49]. Using a high throughput screening MTS assay to check for virus-induced cytopathic effect (CPE), Li and colleagues (2005) screened more than 200 anti-viral Chinese medicinal herb extracts for antiviral activity against the human SARS-CoV. In the end, they reported that lycorine-with an $\mathrm{EC}_{50}$ value of $15.7 \pm 1.2 \mathrm{nM}$, a $\mathrm{CC}_{50}$ in Vero E6 and HepG2 cell lines of 14,980.0 \pm 912.0 and 18,810.0 $\pm 1322.0 \mathrm{nM}$, respectively, and an SI value higher than 900 inhibits SARS-CoV replication in vitro, making it an ideal candidate as a new anti-SARS-CoV drug [30]. Unfortunately, this observation was made post the SARS-CoV outbreak, and could never be tested in an in vivo setting. Moreover, the authors did not speculate on the anti-SARS-CoV mode of action of lycorine. Based on the previous study by Li and colleagues (2005), Zhang and others (2020) tested the inhibitory effect of lycorine on SARS-CoV-2 in in vitro cell culture replication. Using a dose-dependent rescuing CPE assay, they reported that lycorine inhibits SARS-CoV-2 in vitro replication in a cell-independent manner [50]. While previous studies have reported that the antiviral action of lycorine is primarily through the suppression of viral RNA replication [41,45], by blocking the elongation of viral RNA translation during EV71 infection [45], others have reported that lycorine is able to stop the movement of influenza virus nucleoprotein from the nucleus [51] and is able to downregulate autophagy [46]. Based on these previous reports, Zhang and colleagues (2020) postulated that the anti-SARS-CoV-2 activity of lycorine is likely due to the alkaloid modulating host factors instead of directly targeting viral factors [50]; however, this needs to be verified in future studies.

Oxysophoridine belongs to the quinolizidine alkaloid group and is one of the alkaloids extracted from the Chinese medicinal plant Sophora alopecuroides and Siphocampylus verticillatus [52,53]. This alkaloid has various known pharmacological activities, especially in the field of oncology [54], and has anti-oxidative stress, strong anti-inflammatory, and anti-apoptosis properties $[53,55,56]$. Studies investigating the anti-viral properties of this alkaloid have not been very successful but a recent study has reported that SARS-CoV-2 replication is inhibited by oxysophoridine in cell culture $\left(\mathrm{EC}_{50}\right.$ $0.18 \mu \mathrm{M}$ and $\mathrm{CC}_{50}>40 \mu \mathrm{M}$ ) [50]. Little-to-nothing is known about the anti-viral mode of action of 
oxysophoridine, however, and future studies are needed to determine how this alkaloid interferes with coronaviral replication.

The bis-benzylisoquinoline alkaloids tetrandrine (TET), fangchinoline (FAN), and cepharanthine (CEP) are major compounds in Stephania tetrandra and other related species of Menispermaceae; these alkaloids are known for their anticancer and anti-inflammatory activity [31]. The antiviral activities of these alkaloids have also been widely studied. The alkaloid fangchinoline exhibits antiviral activity against HIV1 in MT-4 and PM1 cells [57]. Some studies using cepharanthine showed that its antiviral action against HIV1 is by inhibiting the process of virus entry into cells, reducing the fluidity of the plasma membrane [58]; through a synergic effect with a derivative tetrahydrotetramethylnaphthalene results in inhibition of the proliferation of human T-lymphotropic virus type 1 (HTLV-1) [59]. On the other hand, tetrandrine attenuates the infection caused by the DV in human lung cells [60], inhibits the infection of human macrophages by EV [61], and inhibits HSVI-induced keratitis in mice [62]. Moreover, cepharanthine hydrochloride inhibits the replication of the lamivudine-resistant HBV [63]. A more recent study reported that several bisbenzylisoquinoline alkaloids block MERS-pseudovirus translocation through the endolysosomal system - which normally provides one pathway for cellular entry of MERS-CoV-by inhibiting NAADP-evoked $\mathrm{Ca}^{2+}$ release [64]. In addition, tetrandrine, fangchinoline, and cepharanthine inhibit $\mathrm{HCoV}-\mathrm{OC} 43$-induced cell death in the early stage of infection in human lung cells and reduce virus replication by suppressing the expression of viral $\mathrm{S}$ and $\mathrm{N}$ proteins [31].

Tylophora indica and Tylophora ovata are used as traditional medicines in India [65] and China [66]. Tylophorine and tylophorine analogs, the natural products first isolated from the plant T. indica, are reported to have broad in vivo activity against many diseases, including inflammation [67]—one of the hallmarks of pathogenic coronavirus infection, and can inhibit global protein synthesis [68]. Interestingly, tylophorine has also been reported to inhibit the replication of the HCV [69]. More recent studies have shown that tylophorine-based compounds, whether extracted from plants or artificially synthesized, act as strong inhibitors of many coronaviruses including SARS-CoV, mouse hepatitis virus (MHV), and transmissible gastroenteritis virus (TGEV) [70-72]. One study described natural (tylophorine and tylophorinine) and synthetic tylophorine compounds as novel and potent anti-CoV agents for the treatment of TGEV and SARS-CoV infections. The authors reported $\mathrm{EC}_{50}$ values for the natural and synthetic tylophorine compounds ranging from 8 to $1468 \mathrm{nM}$ and 5 to $340 \mathrm{nM}$, in ST and Vero 76 cells, respectively. Additionally, the tylophorine compounds showed strong anti-coronavirus replication activity, ultimately blocking virus-induced apoptosis and subsequent cytopathic effect in cells in vitro [71]. In a further study to understand the mode of action of tylophorine-based compounds, Yang and colleagues (2017) demonstrated that these compounds target viral RNA, thereby inhibiting TGEV replication. The authors further reported that tylophorine-based compounds act jointly with CYT387-a JAK family inhibitor-to exert comprehensive anti-TGEV activities. They concluded that the combination treatment, using a tylophorine compound and a JAK2 inhibitor, is more efficacious for the treatment of SARS-CoV or MERS-CoV than either treatment on its own [72].

Isatis indigotica is a traditional Chinese medicine used in clinical settings for its anti-viral properties in the treatment of diseases like influenza, hepatitis, and encephalitis [73,74], as well as inflammation [75]. In one study, indigo-a major compound of I. indigotica root extract-showed potent antiviral activity against Japanese encephalitis virus (JEV) in vitro replication in a dose-dependent manner. Moreover, time-of-addition assays showed that indigo exhibits a strong antiviral effect before or during infection, but not after viral cell entry [74]. Chang and colleagues (2012) hypothesized that this indicated that the antiviral mode of action of indigo is associated with the blocking of virus attachment to the cell receptor [74]. Interestingly, I. indigotica root was also frequently used for the prevention and treatment of SARS during the SARS-CoV outbreaks in China, Hong Kong, and Taiwan [76]. In fact, Lin and colleagues (2005) reported that both the I. indigotica root extract, as well as indigo, showed a significant inhibitory effect on SARS-CoV in the micromolar range. Similar to other I. indigotica root compounds, indigo inhibits the cleavage activities of the 3CLpro-a viral replication enzyme that 
mediates the proteolytic processing of coronavirus replicase polypeptides into functional proteins [77], in a dose-dependent manner. In the end, the authors reported indigo $\mathrm{IC}_{50}$ values for cell-free and cell-based assays of $300 \mu \mathrm{M}$ and $752 \mu \mathrm{M}$, respectively; this is indicative of indigo acting as an efficient blocker 3CLpro functioning. Lastly, a $\mathrm{CC}_{50}$ of $7.4 \mathrm{mM}$ in Vero cells was reported indicating that indigo is not toxic to Vero cells [76]. This contradicts the hypothesis for the mode of action for indigo proposed by Chang and colleagues (2012) but could merely be a function of the virus studied or the assays used. Further studies on different viruses, and in different systems, would be needed to elucidate the exact mode of action of indigo.

Strobilanthes cusia is a traditional medicine used in Myanmar, India, Thailand, and the southern parts of China [78]. Historically, the root has been used to treat influenza, encephalitis B, viral pneumonia, epidemic cerebrospinal meningitis, and mumps $[79,80]$. Tryptanthrin and indigodole B are two of the major compounds extracted from S. cusia leaves [81]. In a study by Tsai and colleagues (2020), these compounds showed strong antiviral activity in reducing both the CPE and virus yield (IC $\mathrm{I}_{50}$ values are $1.52 \mu \mathrm{M}$ and $2.60 \mu \mathrm{M}$ for tryptanthrin and indigodole B, respectively) in HCoV-NL63-infected cells. In addition, strong viricidal activity was reported for tryptanthrin $\left(\mathrm{IC}_{50}=0.06 \mu \mathrm{M}\right)$ and indigodole $\mathrm{B}\left(\mathrm{IC}_{50}=2.09 \mu \mathrm{M}\right)$. The authors identified tryptanthrin as the key antiviral compound of $S$. cusia leaf methanol extract with potent activity against HCoV-NL63 in a cell-type independent manner. Lastly, they reported that tryptanthrin interferes with the early and late stages of HCoV-NL63 in vitro replication, by blocking viral RNA synthesis as well as the activity of the papain-like protease 2 [82].

Due to the structural diversity of the alkaloids and the differences in the experimental protocols used by each research group in our selected articles, it is not easy to establish a relationship between chemical structure and anti-coronaviral activity of the alkaloids identified in our review. However, we do note that the identified alkaloids share some common chemical characteristics. Interestingly, the eleven alkaloids are highly oxygenated due to the presence of several functional groups, including methoxyls, hydroxyls, methylene dioxide, and carbonyls of ketones, esters, and amides. Also, the nitrogens found in these alkaloids are heterocyclic atoms and are sometimes in ring fusion, and most importantly, all the alkaloids are made up of polycyclic systems in their chemical structures. It is plausible that these common chemical structures contribute to the anti-coronavirus activity of these alkaloids.

Current data demonstrate the therapeutic potential of these compounds against several viral diseases, including those related to coronaviruses (Table 1), as promising molecules for the study of new drug candidates against the COVID-19. Table 2 showed the activities of alkaloids against other viruses—besides coronaviruses—and the compounds are illustrated in Figure 2.

\section{Molecular Docking Study}

SARS-CoV-2, a pandemic infectious disease resulting in COVID-19, is causing numerous health and economic problems globally. SARS-CoV-2 must bind to specific receptors on the host cell surface that allows virus entry into the host cell. SARS-CoV-2 attaches to angiotensin converting enzyme-2 (ACE2) receptors-the main receptor involved with viral entry-present on the surface of host cells, by anchoring the virus' S1 subunit of the spike protein. The S1 subunit, which contains the receptor binding domain (RBD), is responsible for the high-affinity viral binding to ACE2 receptors [83]; this makes the SARS-CoV-2 S-RBD residues potential targets to control virus entry and infection. 
Table 1. Examples of alkaloids active against coronaviruses.

\begin{tabular}{|c|c|c|c|}
\hline Alkaloid & Coronavirus & Main Finding & Reference \\
\hline \multirow{6}{*}{ Homoharringtonine (HHT) } & SARS-CoV-2 & \multirow{6}{*}{$\begin{array}{l}\mathrm{EC}_{50} 2.10 \mu \mathrm{M} \text { (reduction in viral copy number) } \\
\mathrm{EC}_{50} 2.55 \mu \mathrm{M} \text { (reduction in infectious virus) } \\
\text { Inhibits viral replication } \\
\mathrm{IC}_{50} 11 \mathrm{nM} \\
\mathrm{IC}_{50} 0.112 \mu \mathrm{M} \text { in Vero E6 cells } \\
\text { Decreases viral RNA levels in vivo in piglets } \\
\text { Specific blockage of viral replication }\end{array}$} & {$[3]$} \\
\hline & MHV, BCoV-L9 and & & \\
\hline & HECoV-4408 & & [38] \\
\hline & & & \\
\hline & PEDV & & [37] \\
\hline & & & \\
\hline \multirow[t]{2}{*}{ Lycorine } & SARS-CoV & \multirow{2}{*}{$\begin{array}{l}\mathrm{IC}_{50} 15.7 \mathrm{nM} \\
\text { Anti-CoV activity likely due to the lycorine modulating host factors instead of } \\
\text { directly targeting viral factors }\end{array}$} & [30] \\
\hline & SARS-CoV-2 & & [50] \\
\hline Oxysophoridine & SARS-CoV-2 & $\mathrm{EC}_{50} 0.18 \mu \mathrm{M}$ and $\mathrm{CC}_{50}>40 \mu \mathrm{M}$ & [50] \\
\hline $\begin{array}{c}\text { Tetrandrine, Fangchinoline, and } \\
\text { Cepharanthine }\end{array}$ & $\begin{array}{l}\text { MERS-CoV } \\
\text { HCoV-OC43 }\end{array}$ & $\begin{array}{l}\text { Block MERS-pseudovirus translocation through the endolysosomal system } \\
\text { Inhibited HCoV-OC43-induced cell death in the early stage of infection and } \\
\text { reduced virus replication by suppressing the expression of viral S and N } \\
\text { proteins. }\end{array}$ & $\begin{array}{l}{[64]} \\
{[31]}\end{array}$ \\
\hline $\begin{array}{l}\text { Tylophorine and Tylophorine } \\
\text { analogs }\end{array}$ & $\begin{array}{l}\text { SARS-CoV, MHV, and TGEV } \\
\text { SARS-CoV, MERS-CoV, and TGEV }\end{array}$ & $\begin{array}{l}\text { Anti-CoV replication activity; blocks virus-induced apoptosis and subsequent } \\
\text { cytopathic effect in cells in vitro } \\
\text { EC } 50 \text { values for the natural and synthetic tylophorine compounds } 8 \text { to } 1468 \mathrm{nM} \\
\text { and } 5 \text { to } 340 \mathrm{nM} \text { in ST and Vero } 76 \text { cells, respectively } \\
\text { Targets viral RNA, thereby inhibiting TGEV replication } \\
\text { Acts jointly with JAK family inhibitor for comprehensive anti-CoV }\end{array}$ & $\begin{array}{l}{[71]} \\
{[72]}\end{array}$ \\
\hline Indigo & SARS-CoV & $\begin{array}{l}\text { Inhibits the cleavage activities of the 3CLpro } \\
\mathrm{IC}_{50} \text { values for cell-free and cell-based assays of } 300 \mu \mathrm{M} \text { and } 752 \mu \mathrm{M} \text {, } \\
\text { respectively }\end{array}$ & [76] \\
\hline Tryptanthrin and Indigodole B & HCoV-NL63 & $\begin{array}{l}\text { Reduces viral yield: tryptanthrin }\left(\mathrm{IC}_{50} 1.52 \mu \mathrm{M}\right) \text {; indigodole } \mathrm{B}(2.60 \mu \mathrm{M}) \\
\text { Virucidal activity: tryptanthrin }\left(\mathrm{IC}_{50}=0.06 \mu \mathrm{M}\right) \text {; indigodole } \mathrm{B}\left(\mathrm{IC}_{50}=2.09 \mu \mathrm{M}\right) \\
\text { Tryptanthrin blocks viral RNA genome synthesis and the activity of the } \\
\text { papain-like protease } 2\end{array}$ & [82] \\
\hline
\end{tabular}


Table 2. Bioactivity of alkaloids against other viruses besides the coronavirus.

\begin{tabular}{|c|c|c|c|c|}
\hline Alkaloid & Type of Virus/Cell Lines & Concentration/Dose & Antiviral Effect & Reference \\
\hline Homoharringtonine & $\begin{array}{l}\text { VZV/HFF cells } \\
\text { HBV/HepG2 2.2.15 cells } \\
\text { Echovirus 1/RPE cells } \\
\text { VSV/HEK293T cells } \\
\text { HSV1/Vero cells }\end{array}$ & $\begin{array}{l}10 \mathrm{ng} / \mathrm{mL} \\
0.03 \mu \mathrm{M} \\
2 \mu \mathrm{M} \\
0.12 \mu \mathrm{M} \\
50 \mathrm{nM} \\
139 \mathrm{nM}\end{array}$ & $\begin{array}{l}\text { Down-regulation of VZV lytic gene transcripts } \\
\text { Induces a } 50 \% \text { inhibition in HBsAg release } \\
\text { Induces a } 50 \% \text { inhibition in HBV-DNA release } \\
\text { Inhibit echovirus replication } \\
\text { Inhibits the late stage of vesicular stomatitis virus replication } \\
\text { Inhibits 50\% of HSV1 replication }\end{array}$ & $\begin{array}{l}{[34]} \\
{[35]} \\
{[36]} \\
{[37]}\end{array}$ \\
\hline Tylophorine & $\mathrm{HCV}$ & $0.06 \mu \mathrm{M}$ & Reduced replication of the HCV through inhibition of Cyclin A2 & [69] \\
\hline Fangchinoline & $\begin{array}{l}\text { HIV1/MT-4, PM1, and human } \\
\text { embryonic kidney cell line } \\
\text { 293T cells }\end{array}$ & 0.8 to $1.7 \mu \mathrm{M}$ & $\begin{array}{l}\text { Inhibits HIV1 replication by interfering with gp160 proteolytic } \\
\text { processing }\end{array}$ & [57] \\
\hline Lycorine & $\begin{array}{c}\text { DV-2/A549 cells } \\
\text { ZV/Vero, Huh7, and A549 cells } \\
\text { RD cells } \\
\text { HCV/Huh 7.5 cells } \\
\text { Avian influenza H5N1 } \\
\text { virus/GD178 and MDCK cells } \\
\text { EV-71 H/Vero cells } \\
\text { Coxsackievirus A16/Vero cells }\end{array}$ & $\begin{array}{c}0.8 \mu \mathrm{M} \\
0.22 \text { to } 0.39 \mu \mathrm{M} \\
0.058 \mu \mathrm{g} / \mathrm{mL} \\
0.316 \mu \mathrm{M} \\
0.52 \mu \mathrm{M} \\
2.04 \mu \mathrm{M} \\
3.2 \mu \mathrm{M}\end{array}$ & $\begin{array}{l}\text { Inhibits } 50 \% \text { of envelope protein production } \\
\text { Inhibits } 50 \% \text { of } \mathrm{ZV} \text { protein and envelope biosynthesis } \\
\text { Inhibits } 50 \% \text { of virus replication } \\
\text { Reduces } \mathrm{HCV} \text { replication by } 50 \% \text { through suppresses the } \\
\text { expression of Hsc70 } \\
\text { Reduces the expression of viral proteins } \\
\text { Inhibits } 50 \% \text { of virus replication } \\
\text { Inhibits } 50 \% \text { of virus replication }\end{array}$ & $\begin{array}{l}{[41]} \\
{[42]} \\
{[43]} \\
{[44]} \\
{[47]} \\
{[46]}\end{array}$ \\
\hline Indigo & JEV/BHK-21 cells & $37.5 \mu \mathrm{g} / \mathrm{ml}$ & Inhibits $50 \%$ of virus replication & [74] \\
\hline Tetrandrine & $\begin{array}{l}\text { DV/A549 cells } \\
\text { Ebolavirus/human } \\
\text { macrophages } \\
\text { HSV/BALB/c mice }\end{array}$ & $\begin{array}{c}1-10 \mu \mathrm{M} \\
8 \mu \mathrm{M} \\
15 \mathrm{mg} / \mathrm{kg} \text { (i.p.) }\end{array}$ & $\begin{array}{l}\text { Inhibited the DNA binding activity of NF-kB induced by DV } \\
\text { and suppressed viral production } \\
\text { Inhibited the infection of human macrophages by Ebolavirus } \\
\text { Inhibited keratitis induced by HSV-I }\end{array}$ & $\begin{array}{l}{[60]} \\
{[61]} \\
{[62]}\end{array}$ \\
\hline Cepharanthine & HIV1/Molt-4 T cell line & $5-20 \mu \mathrm{g} / \mathrm{mL}$ & $\begin{array}{l}\text { Inhibited the entry of the virus by reducing the fluidity of the } \\
\text { plasma membrane }\end{array}$ & [58] \\
\hline Cepharanthine hydrochloride & HBV/HepG2 cells & $\begin{array}{c}2.14 \mu \mathrm{M} \\
31.89 \mu \mathrm{M}\end{array}$ & $\begin{array}{l}\text { Inhibited the virus replication } \\
\text { Inhibited HBeAg production }\end{array}$ & [63] \\
\hline
\end{tabular}




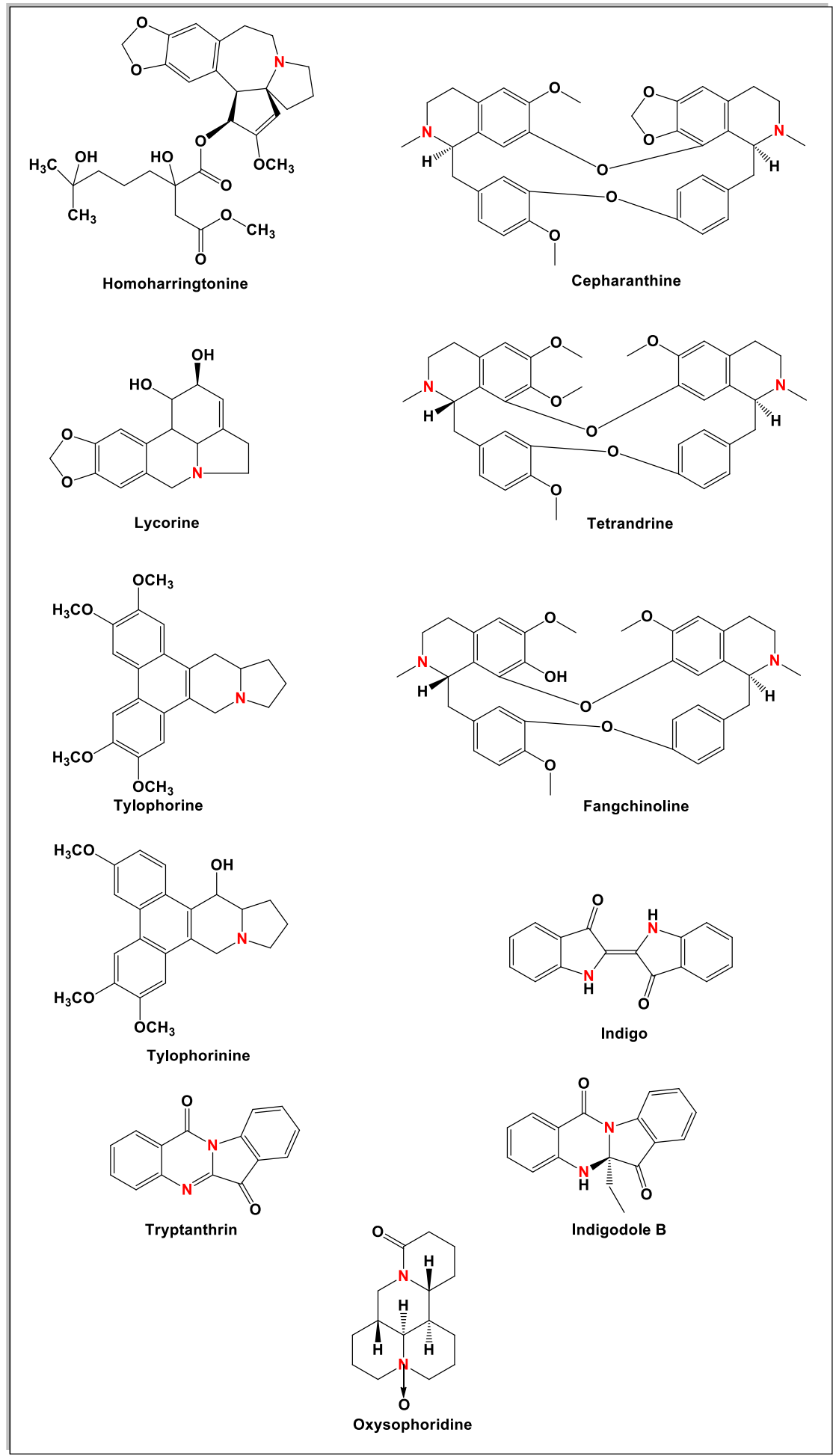

Figure 2. Chemical structures of bioactive alkaloids against coronavirus.

In this study, the S1 subunit of SARS-COV-2 was targeted by an in silico approach to repurpose drug molecules that bind the S-protein and blocks its interaction with the ACE2 receptor, rendering it incapable of infecting a host cell. From a previous study [83], it was reported that several drugs were found from in a high-throughput virtual screening approach of FDA approved LOPAC library drugs to be active against the S-protein receptor of the virus. KT185, KT203, GSK1838705A, BMS195614, and RS504393 were identified to bind at the receptor binding site on the viral S-protein. So, in order to gain insights into the binding mode and crucial molecular interactions of the chosen alkaloids, 
molecular modeling simulation studies were performed with the S-RBD protein of SARSCOV-2 using Libdock protocol in Discovery Studio 2.5 Software. The analysis of their binding modes was performed to predict their biological activities and to achieve further insight into binding orientations and interactions. Alkaloids interacting with S1-RBD could potentially interfere with virus attachment to host receptors and, hence, inhibit virus entry into the host cell. Therefore, a molecular docking study was performed to identify and understand the interaction and binding affinity of these alkaloids with the S1-RBD of SARS-CoV-2.

The outcome of our docking study of the selected alkaloids and reported compounds with SARS-CoV-2 S1-RBD is presented in Table 3. Where the previously reported KT185, KT203, GSK1838705A, BMS195614, and RS504393 gave a libdock score of 95.9, 101.43, 72.7,91.75, and 120 (Kcal/mol), respectively, the chosen alkaloids gave a libdock score ranging from 64.26 (Kcal $/ \mathrm{mol})$ to 109.11 (Kcal/mol). This finding indicated higher binding stability for alkaloids-S1-RDB complexes. In other words, S1-RDB favored interactions with most alkaloids, especially homoharringtonine which revealed the highest docking score. The interaction of homoharringtonine with S1-RBD involved three hydrogen bonds acceptor with Ser494, Ser494, and Gln 493 and two hydrogen bond donors with Tyr453 and Pro491. In addition, there were hydrophobic interactions with Leu455, Lys452, and Phe 497. Also, with cepharanthine, the high docking score $(106.74 \mathrm{Kcal} / \mathrm{mol})$ could be attributed to the formation of five hydrogen bond acceptors with Arg 454, Arg 457, Lys 458, Lys 458, and Ser 469 and one hydrogen bond donor with Gln474. All the docked structures showed similar binding modes in the binding region of S1-RBD of SARS-COV-2 and interaction with various amino acid residues, including the Leu455, Phe486, Asn487, Gln493, Ser494, Tyr495, and Gly496 [83]. This indicated that these compounds have a high probability of binding to the S-RBD protein of SARS-COV-2, preventing it from binding to the host cell.

Table 3. Libdock score of the anti-coronavirus alkaloids and the key amino acids involved in the H-bond interaction with the compounds.

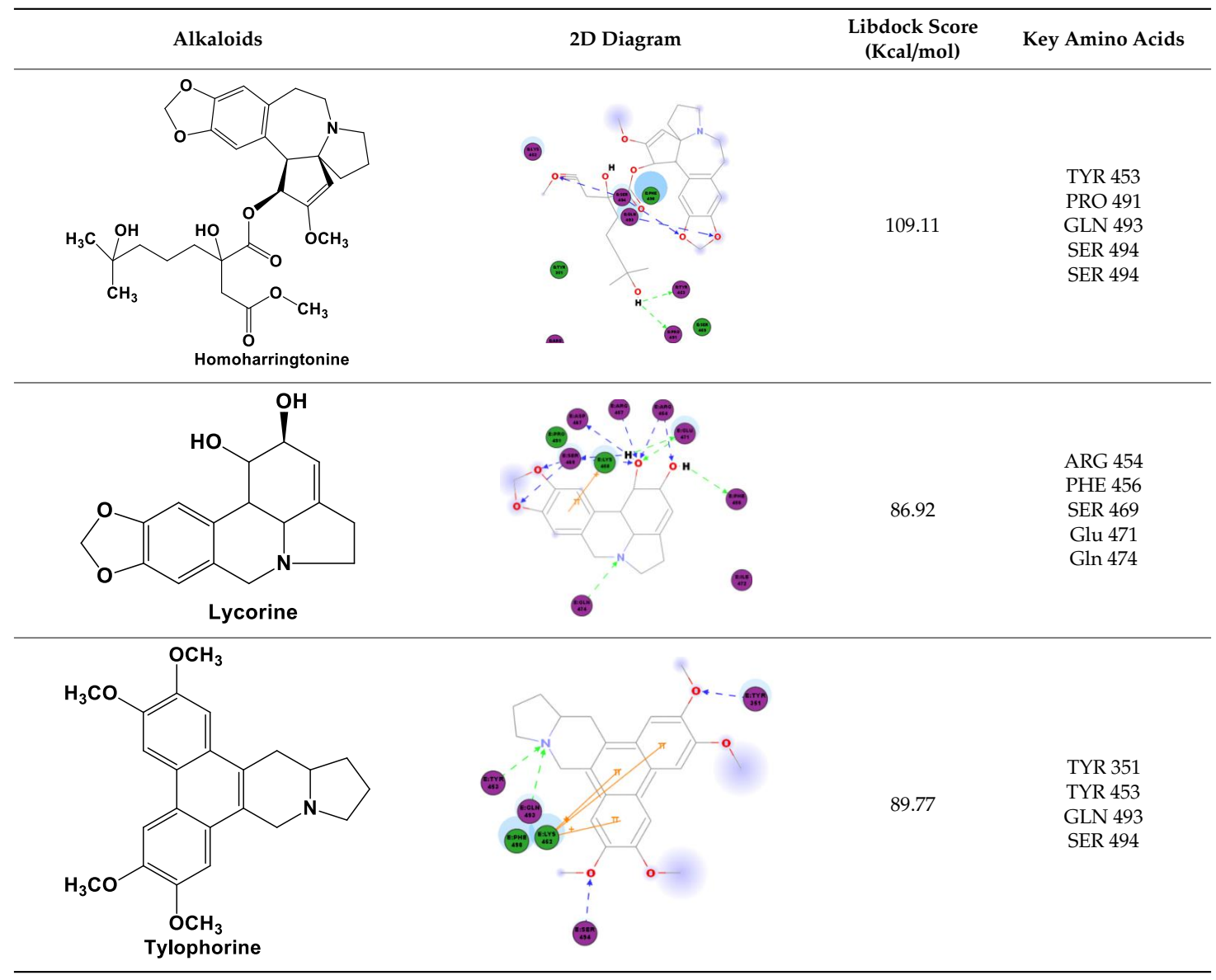


Table 3. Cont.

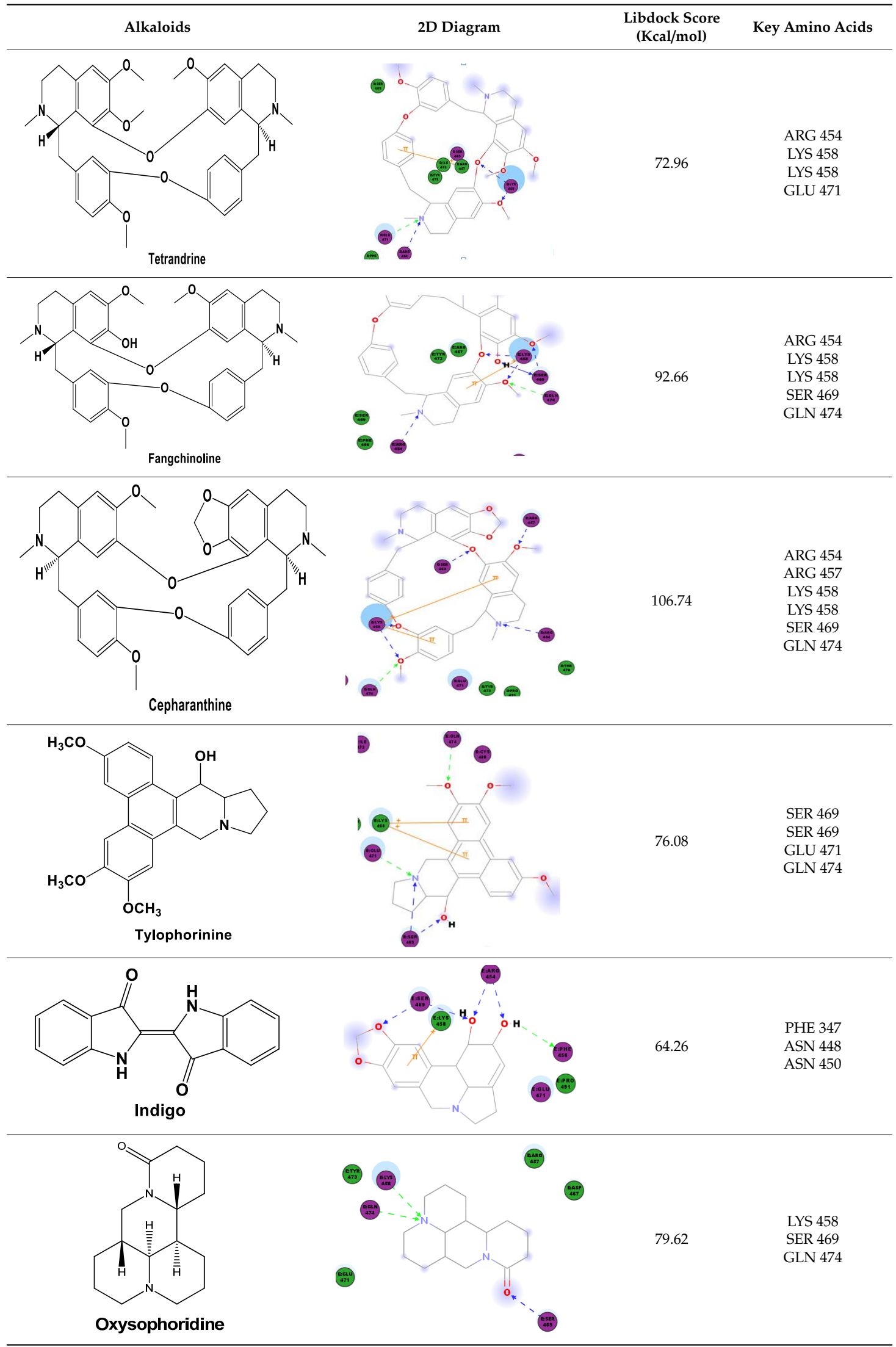


Table 3. Cont

2D Diagram<smiles>CC[C@]12Nc3ccccc3C(=O)N1c1ccccc1C2=O</smiles>

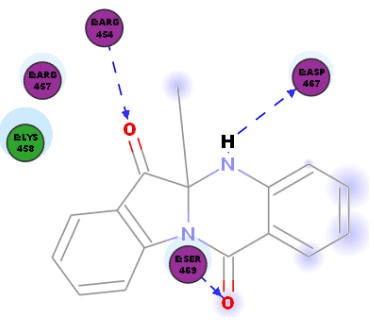

ARG 454

$74.59 \quad$ ASP 467

Indigodole B

\section{Conclusions}

Traditional herbal medicines and plant-based natural compounds are rich resources of new antiviral drugs. In fact, about $25 \%$ of commonly used medicines contain compounds isolated from plants. Many traditional herbal medicines possess antiviral activity against a plethora of viral strains, exerting their antiviral activity on the virus life cycle, including viral entry, replication, assembly, and release, and also the virus-host-specific interactions. Alkaloids have been reported as broad-spectrum inhibitors of animal and human coronaviruses. Whereas the mechanisms used by HHT, oxysophoridine and tylophorine, and tylophorine analogs to inhibit CoV replication are not known, lycorine modulates host factors to interfere with viral replication. On the other hand, tetrandrine, fangchinoline, and cepharanthine block virus translocation through the endolysosomal system or target viral RNA, inhibiting TGEV replication and act jointly with a JAK-family inhibitor for comprehensive anti-CoV activity. Indigo, on the other hand, inhibits the cleavage activities of the 3CLpro to interfere with virus replication. Lastly, tryptanthrin and indigodole B decrease virus yield and have potent viricidal activity. In particular, tryptanthrin was reported to block viral RNA genome synthesis as well as the activity of the papain-like protease 2 in HCoV-NL63-infected cells. As shown in the in silico simulations using biological targets related to SARS-CoV-2 and in some recent in vitro studies, the alkaloids provide an attractive prospect as anti-coronavirus drugs and warrants further investigation.

\section{Methodology}

The present study was carried out based on a search of the literature on alkaloids against human coronaviruses. A search of the literature was performed by using the scientific database PubMed, included studies published until April 2020, and used the following keywords: coronavirus, Human coronavirus-229E (229-E), Human coronavirus-NL63 (NL-63), Human coronavirus-OC43 (OC43), Human coronavirus-HKU1 (HKU1), SARS-CoV, MERS-CoV and SARS-CoV-2 (2019-nCoV or COVID-19), alkaloid, pyrrolidines, pyridines, tropanes, pyrrolizidines, isoquinolines, indoles, quinolines, quinazoline, $\beta$-carboline alkaloid, piperidine, and pyrrole. Articles published in languages other than English were excluded. 


\section{Molecular Docking}

The X-ray crystal structure of the S-RBD protein of SARS-COV-2 was obtained from the Protein Data Bank [www.rcsb.org] (PDB code: 6vw1) [84]. The protein structure was prepared using the default protein preparation tools integrated into the software. This was accomplished by adding hydrogen atoms to the amino acid residues, completing the missing residues, and applying force field parameters by using CHARMm forcefield [85]. All of the protein structures were minimized using 500 steps employing a SMART minimizer algorithm. Also, binding pockets, together with the surrounding amino acid residues, were identified. The ligands were prepared using the ligand preparation protocol of Accelrys Discovery Studio [86]. The ionization $\mathrm{pH}$ was adjusted to 7.4, hydrogen atoms were added and no isomers or tautomers were generated from the ligands. Docking was carried out using Libdock software [87] in the interface of Accelrys Discovery Studio 4.0 [86]. Ten docking poses were generated for each ligand docked and were then thoroughly inspected for proposing the best binding mode. The top-ranked poses were selected for analysis.

Author Contributions: Conceptualization of the original idea, writing the original draft, and final editing of the manuscript, B.C.F. and C.d.S.M.B.F.; molecular docking study and writing, N.S.M.I.; conceptualization, methodology, review and editing, and supervision, D.P.d.S. All authors have read and agreed to the published version of the manuscript.

Funding: Burtram C. Fielding receives funding from the National Research Foundation (NRF) (South Africa) and the University of the Western Cape Senate Research Fund. Any opinion, findings, and conclusions or recommendations expressed in this material are those of the authors and, therefore, the NRF does not accept any liability in regard thereto.

Acknowledgments: This research was supported by the National Council for Scientific and Technological Development (CNPq) and the Coordination for the Improvement of Higher Education Personnel (CAPES).

Conflicts of Interest: No potential conflict of interest was reported by the authors.

\section{Abbreviations}

$\begin{array}{ll}\text { 229-E } & \text { Human coronavirus-229E } \\ \text { 3CLpro } & \text { 3C-like protease } \\ \text { BCoV-L9 } & \text { Bovine coronavirus strain L9 } \\ \text { CEP } & \text { Cepharanthine } \\ \text { CoVs } & \text { Coronaviruses } \\ \text { COVID-19 } & \text { Coronavirus disease 2019 } \\ \text { CPE } & \text { Cytopathic effect } \\ \text { DV } & \text { Dengue virus } \\ \text { EV } & \text { Ebolavirus } \\ \text { EV-71 } & \text { Enterovirus 71 } \\ \text { FAN } & \text { Fangchinoline } \\ \text { HBV } & \text { Hepatitis B virus } \\ \text { HCMV } & \text { Human cytomegalovirus } \\ \text { HCV } & \text { Hepatitis C virus } \\ \text { HECoV-4408 } & \text { Human enteric coronavirus-4408 } \\ \text { HEV1 } & \text { Human echovirus 1 } \\ \text { HHT } & \text { Homoharringtonine } \\ \text { HIV } & \text { Human immunodeficiency virus } \\ \text { HKU1 } & \text { Human coronavirus-HKU1 } \\ \text { HSV1 } & \text { Human T-lymphotropic virus type } \\ \text { HTLV-1 } & \text { Herpes simplex virus type 1 } \\ \text { JEV } & \text { Japanese encephalitis virus } \\ \text { MERS-CoV } & \text { Middle east respiratory syndrome-coronavirus } \\ \text { MHV } & \text { Mouse hepatitis virus } \\ \text { NDV } & \text { Newcastle disease virus } \\ & \end{array}$




$\begin{array}{ll}\text { NL63 } & \text { Human coronavirus-NL63 } \\ \text { OC43 } & \text { Human coronavirus-OC43 } \\ \text { PEDV } & \text { Porcine epidemic diarrhoea coronavirus } \\ \text { PLpro } & \text { Papain-like protease } \\ \text { RVFV } & \text { Rift Valley fever virus } \\ \text { SARS-CoV } & \text { Severe acute respiratory syndrome-coronavirus } \\ \text { SARS-CoV-2 } & \text { Severe acute respiratory syndrome-coronavirus-2 } \\ \text { S-RBD } & \text { Spike protein receptor-binding domain } \\ \text { TET } & \text { Bis-benzylisoquinoline alkaloids tetrandrine } \\ \text { TGEV } & \text { Transmissible gastroenteritis coronavirus } \\ \text { VSV } & \text { Vesicular stomatitis virus } \\ \text { VZV } & \text { Varicella-zoster virus } \\ \text { ZV } & \text { Zika virus }\end{array}$

\section{References}

1. Sanders, J.M.; Monogue, M.L.; Jodlowski, T.Z.; Cutrell, J.B. Pharmacologic treatments for coronavirus disease 2019 (COVID-19): A review. JAMA 2020, 323, 1824-1836. [CrossRef] [PubMed]

2. Fuzimoto, A.D.; Isidoro, C. The antiviral and the coronavirus-host protein pathways inhibiting properties of herbs and natural compounds-Additional weapons in the fight against the COVID-19 pandemic? J. Tradit. Complement. Med. 2020. [CrossRef] [PubMed]

3. Choy, K.-T.; Wong, A.Y.-L.; Kaewpreedee, P.; Sia, S.-F.; Chen, D.; Hui, K.P.Y.; Chu, D.K.W.; Chan, M.C.W.; Cheung, P.P.-H.; Huang, X. Remdesivir, lopinavir, emetine, and homoharringtonine inhibit SARS-CoV-2 replication in vitro. Antivir. Res. 2020, 104786. [CrossRef] [PubMed]

4. Kishimoto, S.; Sato, M.; Tsunematsu, Y.; Watanabe, K. Evaluation of Biosynthetic Pathway and Engineered Biosynthesis of Alkaloids. Molecules 2016, 21, 1078. [CrossRef]

5. Aniszewski, T. Alkaloids: Chemistry, Biology, Ecology, and Applications; Elsevier: Amsterdam, The Netherlands, 2015; ISBN 0444594620.

6. Martin, N.J.; Ferreiro, S.F.; Barbault, F.; Nicolas, M.; Lecellier, G.; Paetz, C.; Gaysinski, M.; Alonso, E.; Thomas, O.P.; Botana, L.M.; et al. Indole alkaloids from the Marquesan plant Rauvolfia nukuhivensis and their effects on ion channels. Phytochemistry 2015, 109, 84-95. [CrossRef]

7. Chen, Q.-B.; Gao, J.; Zou, G.-A.; Xin, X.-L.; Aisa, H.A. Piperidine Alkaloids with Diverse Skeletons from Anacyclus pyrethrum. J. Nat. Prod. 2018, 81, 1474-1482. [CrossRef]

8. Yu, X.; Gao, X.; Zhu, Z.; Cao, Y.; Zhang, Q.; Tu, P.; Chai, X. Alkaloids from the Tribe Bocconieae (Papaveraceae): A Chemical and Biological Review. Molecules 2014, 19, 13042-13060. [CrossRef]

9. Arato Ferreira, P.H.; dos Santos, D.A.P.; da Silva, M.F.D.G.; Vieira, P.C.; King-Diaz, B.; Lotina-Hennsen, B.; Veiga, T.A.M. Acridone Alkaloids from Swinglea glutinosa (Rutaceae) and Their Effects on Photosynthesis. Chem. Biodivers. 2016, 13, 100-106. [CrossRef]

10. Heinig, U.; Aharoni, A. Analysis of Steroidal Alkaloids and Saponins in Solanaceae Plant Extracts Using UPLC-qTOF Mass Spectrometry; Humana Press: New York, NY, USA, 2014; pp. 171-185.

11. Oliveira, S.L.; da Silva, M.S.; Tavares, J.F.; Sena-Filho, J.G.; Lucena, H.F.S.; Romero, M.A.V.; Barbosa-Filho, J.M. Tropane Alkaloids from Erythroxylum Genus: Distribution and Compilation of ${ }^{13} \mathrm{C}-\mathrm{NMR}$ Spectral Data. Chem. Biodivers. 2010, 7, 302-326. [CrossRef]

12. He, L.-J.; Liu, J.-S.; Luo, D.; Zheng, Y.-R.; Zhang, Y.-B.; Wang, G.-C.; Li, Y.-L. Quinolizidine alkaloids from Sophora tonkinensis and their anti-inflammatory activities. Fitoterapia 2019, 139, 104391. [CrossRef]

13. Brook, K.; Bennett, J.; Desai, S.P. The Chemical History of Morphine: An 8000-year Journey, from Resin to de-novo Synthesis. J. Anesth. Hist. 2017, 3, 50-55. [CrossRef] [PubMed]

14. Cushnie, T.P.T.; Cushnie, B.; Lamb, A.J. Alkaloids: An overview of their antibacterial, antibiotic-enhancing and antivirulence activities. Int. J. Antimicrob. Agents 2014, 44, 377-386. [CrossRef] [PubMed]

15. Khan, H.; Mubarak, M.S.; Amin, S. Antifungal Potential of Alkaloids As An Emerging Therapeutic Target. Curr. Drug Targets 2017, 18. [CrossRef] [PubMed]

16. Thompson, P.L.; Nidorf, S.M. Colchicine: An Affordable Anti-Inflammatory Agent for Atherosclerosis. Curr. Opin. Lipidol. 2018, 29, 467-473. [CrossRef] [PubMed] 
17. Manayi, A.; Nabavi, S.M.; Setzer, W.N.; Jafari, S. Piperine as a Potential Anti-cancer Agent: A Review on Preclinical Studies. Curr. Med. Chem. 2019, 25, 4918-4928. [CrossRef]

18. Xu, W.; Zhang, M.; Liu, H.; Wei, K.; He, M.; Li, X.; Hu, D.; Yang, S.; Zheng, Y. Antiviral activity of aconite alkaloids from Aconitum carmichaelii Debx. Nat. Prod. Res. 2019, 33, 1486-1490. [CrossRef]

19. Hung, T.-C.; Jassey, A.; Liu, C.-H.; Lin, C.-J.; Lin, C.-C.; Wong, S.H.; Wang, J.Y.; Yen, M.-H.; Lin, L.-T. Berberine inhibits hepatitis $C$ virus entry by targeting the viral E2 glycoprotein. Phytomedicine 2019, 53, 62-69. [CrossRef]

20. Luganini, A.; Mercorelli, B.; Messa, L.; Palù, G.; Gribaudo, G.; Loregian, A. The isoquinoline alkaloid berberine inhibits human cytomegalovirus replication by interfering with the viral Immediate Early-2 (IE2) protein transactivating activity. Antivir. Res. 2019, 164, 52-60. [CrossRef]

21. Varghese, F.S.; Thaa, B.; Amrun, S.N.; Simarmata, D.; Rausalu, K.; Nyman, T.A.; Merits, A.; McInerney, G.M.; Ng, L.F.P.; Ahola, T. The Antiviral Alkaloid Berberine Reduces Chikungunya Virus-Induced Mitogen-Activated Protein Kinase Signaling. J. Virol. 2016, 90, 9743-9757. [CrossRef]

22. Diosa-Toro, M.; Troost, B.; van de Pol, D.; Heberle, A.M.; Urcuqui-Inchima, S.; Thedieck, K.; Smit, J.M. Tomatidine, a novel antiviral compound towards dengue virus. Antivir. Res. 2019, 161, 90-99. [CrossRef]

23. McMahon, J.B.; Currens, M.J.; Gulakowski, R.J.; Buckheit, R.W.; Lackman-Smith, C.; Hallock, Y.F.; Boyd, M.R. Michellamine B, a novel plant alkaloid, inhibits human immunodeficiency virus-induced cell killing by at least two distinct mechanisms. Antimicrob. Agents Chemother. 1995, 39, 484-488. [CrossRef] [PubMed]

24. Dai, J.-P.; Wang, Q.-W.; Su, Y.; Gu, L.-M.; Deng, H.-X.; Chen, X.-X.; Li, W.-Z.; Li, K.-S. Oxymatrine Inhibits Influenza A Virus Replication and Inflammation via TLR4, p38 MAPK and NF-кB Pathways. Int. J. Mol. Sci. 2018, 19, 965. [CrossRef] [PubMed]

25. Ho, Y.-J.; Lu, J.-W.; Huang, Y.-L.; Lai, Z.-Z. Palmatine inhibits Zika virus infection by disrupting virus binding, entry, and stability. Biochem. Biophys. Res. Commun. 2019, 518, 732-738. [CrossRef] [PubMed]

26. Moradi, M.-T.; Karimi, A.; Rafieian-Kopaei, M.; Fotouhi, F. In vitro antiviral effects of Peganum harmala seed extract and its total alkaloids against Influenza virus. Microb. Pathog. 2017, 110, 42-49. [CrossRef] [PubMed]

27. Nawawi, A.; Nakamura, N.; Meselhy, M.R.; Hattori, M.; Kurokawa, M.; Shiraki, K.; Kashiwaba, N.; Ono, M. In vivo Antiviral Activity of Stephania cepharantha against Herpes Simplex Virus Type-1. Phyther. Res. 2001, 15, 497-500. [CrossRef] [PubMed]

28. Peng, J.; Zheng, T.-T.; Li, X.; Liang, Y.; Wang, L.-J.; Huang, Y.-C.; Xiao, H.-T. Plant-Derived Alkaloids: The Promising Disease-Modifying Agents for Inflammatory Bowel Disease. Front. Pharmacol. 2019, 10. [CrossRef] [PubMed]

29. Thawabteh, A.; Juma, S.; Bader, M.; Karaman, D.; Scrano, L.; Bufo, S.A.; Karaman, R. The Biological Activity of Natural Alkaloids against Herbivores, Cancerous Cells and Pathogens. Toxins 2019, 11, 656. [CrossRef]

30. Li, S.; Chen, C.; Zhang, H.; Guo, H.; Wang, H.; Wang, L.; Zhang, X.; Hua, S.; Yu, J.; Xiao, P. Identification of natural compounds with antiviral activities against SARS-associated coronavirus. Antivir. Res. 2005, 67, $18-23$. [CrossRef]

31. Kim, D.; Min, J.; Jang, M.; Lee, J.; Shin, Y.; Park, C.; Song, J.; Kim, H.; Kim, S.; Jin, Y.-H.; et al. Natural Bis-Benzylisoquinoline Alkaloids-Tetrandrine, Fangchinoline, and Cepharanthine, Inhibit Human Coronavirus OC43 Infection of MRC-5 Human Lung Cells. Biomolecules 2019, 9, 696. [CrossRef]

32. Kantarjian, H.M.; O'Brien, S.; Cortes, J. Homoharringtonine/Omacetaxine Mepesuccinate: The Long and Winding Road to Food and Drug Administration Approval. Clin. Lymphoma Myeloma Leuk. 2013, 13, 530-533. [CrossRef]

33. Lü, S.; Wang, J. Homoharringtonine and omacetaxine for myeloid hematological malignancies. J. Hematol. Oncol. 2014, 7, 2. [CrossRef] [PubMed]

34. Kim, J.-E.; Song, Y.-J. Anti-varicella-zoster virus activity of cephalotaxine esters in vitro. J. Microbiol. 2019, 57, 74-79. [CrossRef] [PubMed]

35. Romero, M.; Serrano, M.; Efferth, T.; Alvarez, M.; Marin, J. Effect of Cantharidin, Cephalotaxine and Homoharringtonine on "in vitro" Models of Hepatitis B Virus (HBV) and Bovine Viral Diarrhoea Virus (BVDV) Replication. Planta Med. 2007, 73, 552-558. [CrossRef] [PubMed]

36. Andersen, P.I.; Krpina, K.; Ianevski, A.; Shtaida, N.; Jo, E.; Yang, J.; Koit, S.; Tenson, T.; Hukkanen, V.; Anthonsen, M.W.; et al. Novel Antiviral Activities of Obatoclax, Emetine, Niclosamide, Brequinar, and Homoharringtonine. Viruses 2019, 11, 964. [CrossRef] [PubMed] 
37. Dong, H.-J.; Wang, Z.-H.; Meng, W.; Li, C.-C.; Hu, Y.-X.; Zhou, L.; Wang, X.-J. The Natural Compound Homoharringtonine Presents Broad Antiviral Activity In Vitro and In Vivo. Viruses 2018, 10, 601. [CrossRef]

38. Cao, J.; Forrest, J.C.; Zhang, X. A screen of the NIH Clinical Collection small molecule library identifies potential anti-coronavirus drugs. Antivir. Res. 2015, 114, 1-10. [CrossRef] [PubMed]

39. Cao, Z.; Yang, P.; Zhou, Q. Multiple biological functions and pharmacological effects of lycorine. Sci. China Chem. 2013, 56, 1382-1391. [CrossRef]

40. Saltan Çitoğlu, G.; Bahadır Acıkara, Ö.; Sever Yılmaz, B.; Özbek, H. Evaluation of analgesic, anti-inflammatory and hepatoprotective effects of lycorine from Sternbergia fisheriana (Herbert) Rupr. Fitoterapia 2012, 83, 81-87. [CrossRef]

41. Wang, P.; Li, L.-F.; Wang, Q.-Y.; Shang, L.-Q.; Shi, P.-Y.; Yin, Z. Anti-Dengue-Virus Activity and Structure-Activity Relationship Studies of Lycorine Derivatives. ChemMedChem 2014, 9, 1522-1533. [CrossRef]

42. Chen, H.; Lao, Z.; Xu, J.; Li, Z.; Long, H.; Li, D.; Lin, L.; Liu, X.; Yu, L.; Liu, W.; et al. Antiviral activity of lycorine against Zika virus in vivo and in vitro. Virology 2020, 546, 88-97. [CrossRef]

43. Oluyemisi, O.O.; Oriabure, A.E.; Adekunle, A.J.; Ramsay, K.S.T.; Shyyaula, S.; Choudhary, M.I. Bioassay-guided isolation of Poliovirus-inhibiting constituents from Zephyranthes candida. Pharm. Biol. 2015, 53, 882-887. [CrossRef] [PubMed]

44. Chen, D.; Cai, J.; Cheng, J.; Jing, C.; Yin, J.; Jiang, J.; Peng, Z.; Hao, X. Design, Synthesis and Structure-Activity Relationship Optimization of Lycorine Derivatives for HCV Inhibition. Sci. Rep. 2015, 5, 14972. [CrossRef] [PubMed]

45. Liu, J.; Yang, Y.; Xu, Y.; Ma, C.; Qin, C.; Zhang, L. Lycorine reduces mortality of human enterovirus 71-infected mice by inhibiting virus replication. Virol. J. 2011, 8, 483. [CrossRef] [PubMed]

46. Wang, H.; Guo, T.; Yang, Y.; Yu, L.; Pan, X.; Li, Y. Lycorine Derivative LY-55 Inhibits EV71 and CVA16 Replication Through Downregulating Autophagy. Front. Cell. Infect. Microbiol. 2019, 9. [CrossRef]

47. Yang, L.; Zhang, J.H.; Zhang, X.L.; Lao, G.J.; Su, G.M.; Wang, L.; Li, Y.L.; Ye, W.C.; He, J. Tandem mass tag-based quantitative proteomic analysis of lycorine treatment in highly pathogenic avian influenza H5N1 virus infection. PeerJ 2019, 7, e7697. [CrossRef]

48. Renard-Nozaki, J.; Kim, T.; Imakura, Y.; Kihara, M.; Kobayashi, S. Effect of alkaloids isolated from Amaryllidaceae on herpes simplex virus. Res. Virol. 1989, 140, 115-128. [CrossRef]

49. Gabrielsen, B.; Monath, T.P.; Huggins, J.W.; Kefauver, D.F.; Pettit, G.R.; Groszek, G.; Hollingshead, M.; Kirsi, J.J.; Shannon, W.M.; Schubert, E.M.; et al. Antiviral (RNA) Activity of Selected Amaryllidaceae Isoquinoline Constituents and Synthesis of Related Substances. J. Nat. Prod. 1992, 55, 1569-1581. [CrossRef]

50. Zhang, Y.-N.; Zhang, Q.-Y.; Li, X.-D.; Xiong, J.; Xiao, S.-Q.; Wang, Z.; Zhang, Z.-R.; Deng, C.-L.; Yang, X.-L.; Wei, H.-P.; et al. Gemcitabine, lycorine and oxysophoridine inhibit novel coronavirus (SARS-CoV-2) in cell culture. Emerg. Microbes Infect. 2020, 9, 1170-1173. [CrossRef]

51. He, J.; Qi, W.-B.; Wang, L.; Tian, J.; Jiao, P.-R.; Liu, G.-Q.; Ye, W.-C.; Liao, M. Amaryllidaceae alkaloids inhibit nuclear-to-cytoplasmic export of ribonucleoprotein (RNP) complex of highly pathogenic avian influenza virus H5N1. Influenza Other Respi. Viruses 2013, 7, 922-931. [CrossRef]

52. Rui, C.; Yuxiang, L.; Ning, J.; Ningtian, M.; Qingluan, Z.; Yinju, H.; Ru, Z.; Lin, M.; Tao, S.; Jianqiang, Y. Anti-apoptotic and Neuroprotective Effects of Oxysophoridine on Cerebral Ischemia Both In Vivo and In Vitro. Planta Med. 2013, 79, 916-923. [CrossRef]

53. Wang, Y.-S.; Li, Y.-X.; Zhao, P.; Wang, H.-B.; Zhou, R.; Hao, Y.-J.; Wang, J.; Wang, S.-J.; Du, J.; Ma, L.; et al. Anti-inflammation Effects of Oxysophoridine on Cerebral Ischemia-Reperfusion Injury in Mice. Inflammation 2015, 38, 2259-2268. [CrossRef] [PubMed]

54. Yao, X.; Zhang, Y.; Long, W.; Liu, P. Oxysophoridine suppresses the growth of hepatocellular carcinoma in mice: In Vivo and cDNA microarray studies. Chin. J. Integr. Med. 2012, 18, 209-213. [CrossRef] [PubMed]

55. Yang, G.; Gao, J.; Jia, Y.; Yan, L.; Yu, J.; Jiang, Y. Oxysophoridine through intrathecal injection induces antinociception and increases the expression of the GABAA $\alpha 1$ receptor in the spinal cord of mice. Planta Med. 2012, 78, 874-880. [CrossRef] [PubMed]

56. Cao, Z.; Chen, L.; Liu, Y.; Peng, T. Oxysophoridine rescues spinal cord injury via anti-inflammatory, anti-oxidative stress and anti-apoptosis effects. Mol. Med. Rep. 2017. [CrossRef]

57. Wan, Z.; Lu, Y.; Liao, Q.; Wu, Y.; Chen, X. Fangchinoline Inhibits Human Immunodeficiency Virus Type 1 Replication by Interfering with gp160 Proteolytic Processing. PLoS ONE 2012, 7, e39225. [CrossRef] 
58. Matsuda, K.; Hattori, S.; Komizu, Y.; Kariya, R.; Ueoka, R.; Okada, S. Cepharanthine inhibited HIV-1 cell-cell transmission and cell-free infection via modification of cell membrane fluidity. Bioorg. Med. Chem. Lett. 2014, 24, 2115-2117. [CrossRef]

59. Toyama, M.; Hamasaki, T.; UTO, T.; Aoyama, H.; Okamoto, M.; Hashmoto, Y.; Baba, M. Synergistic inhibition of HTLV-1-infected cell proliferation by combination of cepharanthine and a tetramethylnaphthalene derivative. Anticancer Res. 2012, 32, 2639-2645.

60. Liou, J.-T.; Chen, Z.-Y.; Ho, L.-J.; Yang, S.-P.; Chang, D.-M.; Liang, C.-C.; Lai, J.-H. Differential effects of triptolide and tetrandrine on activation of COX-2, NF- $\mathrm{B}$, and AP-1 and virus production in dengue virus-infected human lung cells. Eur. J. Pharmacol. 2008, 589, 288-298. [CrossRef]

61. Sakurai, Y.; Kolokoltsov, A.A.; Chen, C.-C.; Tidwell, M.W.; Bauta, W.E.; Klugbauer, N.; Grimm, C.; Wahl-Schott, C.; Biel, M.; Davey, R.A. Two-pore channels control Ebola virus host cell entry and are drug targets for disease treatment. Science 2015, 347, 995-998. [CrossRef]

62. Hu, S.; Dutt, J.; Zhao, T.; Foster, C.S. Tetrandrine potently inhibits herpes simplex virus type-1-induced keratitis in BALB/c mice. Ocul. Immunol. Inflamm. 1997, 5, 173-180. [CrossRef]

63. Zhou, Y.-B.; Wang, Y.-F.; Zhang, Y.; Zheng, L.-Y.; Yang, X.-A.; Wang, N.; Jiang, J.-H.; Ma, F.; Yin, D.-T.; Sun, C.-Y.; et al. In vitro activity of cepharanthine hydrochloride against clinical wild-type and lamivudine-resistant hepatitis B virus isolates. Eur. J. Pharmacol. 2012, 683, 10-15. [CrossRef] [PubMed]

64. Gunaratne, G.S.; Yang, Y.; Li, F.; Walseth, T.F.; Marchant, J.S. NAADP-dependent Ca2+ signaling regulates Middle East respiratory syndrome-coronavirus pseudovirus translocation through the endolysosomal system. Cell Calcium 2018, 75, 30-41. [CrossRef] [PubMed]

65. Raina, V.; Raina, S. The responsiveness of leukocyte adenyl cyclase to tylophorine in asthmatic subjects. Biochem. Biophys. Res. Commun. 1980, 94, 1074-1077. [CrossRef]

66. You, X.; Pan, M.; Gao, W.; Shiah, H.-S.; Tao, J.; Zhang, D.; Koumpouras, F.; Wang, S.; Zhao, H.; Madri, J.A.; et al. Effects of a novel tylophorine analog on collagen-induced arthritis through inhibition of the innate immune response. Arthritis Rheum. 2006, 54, 877-886. [CrossRef]

67. Yang, C.-W.; Chuang, T.-H.; Wu, P.-L.; Huang, W.-H.; Lee, S.-J. Anti-inflammatory effects of 7-methoxycryptopleurine and structure-activity relations of phenanthroindolizidines and phenanthroquinolizidines. Biochem. Biophys. Res. Commun. 2007, 354, 942-948. [CrossRef]

68. Wang, Y.; Lee, S.; Ha, Y.; Lam, W.; Chen, S.-R.; Dutschman, G.E.; Gullen, E.A.; Grill, S.P.; Cheng, Y.; Fürstner, A.; et al. Tylophorine Analogs Allosterically Regulates Heat Shock Cognate Protein 70 And Inhibits Hepatitis C Virus Replication. Sci. Rep. 2017, 7, 10037. [CrossRef]

69. Pham, L.V.; Ngo, H.T.T.; Lim, Y.-S.; Hwang, S.B. Hepatitis C virus non-structural $5 B$ protein interacts with cyclin A2 and regulates viral propagation. J. Hepatol. 2012, 57, 960-966. [CrossRef]

70. Lee, Y.-Z.; Yang, C.-W.; Hsu, H.-Y.; Qiu, Y.-Q.; Yeh, T.-K.; Chang, H.-Y.; Chao, Y.-S.; Lee, S.-J. Synthesis and Biological Evaluation of Tylophorine-Derived Dibenzoquinolines as Orally Active Agents: Exploration of the Role of Tylophorine E Ring on Biological Activity. J. Med. Chem. 2012, 55, 10363-10377. [CrossRef]

71. Yang, C.-W.; Lee, Y.-Z.; Kang, I.-J.; Barnard, D.L.; Jan, J.-T.; Lin, D.; Huang, C.-W.; Yeh, T.-K.; Chao, Y.-S.; Lee, S.-J Identification of phenanthroindolizines and phenanthroquinolizidines as novel potent anti-coronaviral agents for porcine enteropathogenic coronavirus transmissible gastroenteritis virus and human severe acute respiratory syndrome coronavirus. Antivir. Res. 2010, 88, 160-168. [CrossRef]

72. Yang, C.-W.; Lee, Y.-Z.; Hsu, H.-Y.; Shih, C.; Chao, Y.-S.; Chang, H.-Y.; Lee, S.-J. Targeting Coronaviral Replication and Cellular JAK2 Mediated Dominant NF-кB Activation for Comprehensive and Ultimate Inhibition of Coronaviral Activity. Sci. Rep. 2017, 7, 4105. [CrossRef]

73. Qin, G.; Xu, R. Recent advances on bioactive natural products from Chinese medicinal plants. Med. Res. Rev. 1998, 18, 375-382. [CrossRef]

74. Chang, S.-J.; Chang, Y.-C.; Lu, K.-Z.; Tsou, Y.-Y.; Lin, C.-W. Antiviral Activity of Isatis indigotica Extract and Its Derived Indirubin against Japanese Encephalitis Virus. Evid. Based Complement. Altern. Med. 2012, 2012, 1-7. [CrossRef]

75. Ho, Y.-L.; Chang, Y.-S. Studies on the antinociceptive, anti-inflammatory and antipyretic effects of Isatis indigotica root. Phytomedicine 2002, 9, 419-424. [CrossRef] [PubMed]

76. Lin, C.-W.; Tsai, F.-J.; Tsai, C.-H.; Lai, C.-C.; Wan, L.; Ho, T.-Y.; Hsieh, C.-C.; Chao, P.-D.L. Anti-SARS coronavirus 3C-like protease effects of Isatis indigotica root and plant-derived phenolic compounds. Antivir. Res. 2005, 68, 36-42. [CrossRef] [PubMed] 
77. Berry, M.; Fielding, B.; Gamieldien, J. Potential Broad Spectrum Inhibitors of the Coronavirus 3CLpro: A Virtual Screening and Structure-Based Drug Design Study. Viruses 2015, 7, 6642-6660. [CrossRef] [PubMed]

78. Shahni, R.; Handique, P.J. Antibacterial properties of leaf extracts of Strobilanthes cusia (Nees) Kuntze, a rare ethno-medicinal plant of Manipur, India. Int. J. PharmTech Res. 2013, 5, 1281-1285.

79. Tanaka, T.; Ikeda, T.; Kaku, M.; Zhu, X.-H.; Okawa, M.; Yokomizo, K.; Uyeda, M.; Nohara, T. A New Lignan Glycoside and Phenylethanoid Glycosides from Strobilanthes cusia BREMEK. Chem. Pharm. Bull. 2004, 52, 1242-1245. [CrossRef]

80. Gu, W.; Wang, W.; Li, X.; Zhang, Y.; Wang, L.; Yuan, C.; Huang, L.; Hao, X. A novel isocoumarin with anti-influenza virus activity from Strobilanthes cusia. Fitoterapia 2015, 107, 60-62. [CrossRef]

81. Lee, C.-L.; Wang, C.-M.; Hu, H.-C.; Yen, H.-R.; Song, Y.-C.; Yu, S.-J.; Chen, C.-J.; Li, W.-C.; Wu, Y.-C. Indole alkaloids indigodoles A-C from aerial parts of Strobilanthes cusia in the traditional Chinese medicine Qing Dai have anti-IL-17 properties. Phytochemistry 2019, 162, 39-46. [CrossRef]

82. Tsai, Y.-C.; Lee, C.-L.; Yen, H.-R.; Chang, Y.-S.; Lin, Y.-P.; Huang, S.-H.; Lin, C.-W. Antiviral Action of Tryptanthrin Isolated from Strobilanthes cusia Leaf against Human Coronavirus NL63. Biomolecules 2020, 10, 366. [CrossRef]

83. Choudhary, S.; Malik, Y.S.; Tomar, S. Identification of SARS-CoV-2 cell entry inhibitors by drug repurposing using in silico structure-based virtual screening approach. Front. Immunol. 2020, 11, 1664. [CrossRef] [PubMed]

84. Shang, J.; Ye, G.; Shi, K.; Wan, Y.S.; Aihara, H.; Li, F. Structure of 2019-nCoV chimeric receptor-binding domain complexed with its receptor human ACE2. Worldw. Protein Data Bank 2020. [CrossRef]

85. Brooks, B.R.; Bruccoleri, R.E.; Olafson, B.D.; States, D.J.; Swaminathan, S.A.; Karplus, M. CHARMM: A program for macromolecular energy, minimization, and dynamics calculations. J. Comput. Chem. 1983, 4, 187-217. [CrossRef]

86. Chandrashekharappa, S.; Venugopala, K.N.; Tratrat, C.; Mahomoodally, F.M.; Aldhubiab, B.E.; Haroun, M.; Venugopala, R.; Mohan, M.K.; Kulkarni, R.S.; Attimarad, M.V. Efficient synthesis and characterization of novel indolizines: Exploration of in vitro COX-2 inhibitory activity and molecular modelling studies. New J. Chem. 2018, 42, 4893-4901. [CrossRef]

87. Wu, H.; Liu, Y.; Guo, M.; Xie, J.; Jiang, X. A Virtual Screening Method for Inhibitory Peptides of Angiotensin I-Converting Enzyme. J. Food Sci. 2014, 79, C1635-C1642. [CrossRef]

Sample Availability: Samples of the compounds are not available from the authors.

Publisher's Note: MDPI stays neutral with regard to jurisdictional claims in published maps and institutional affiliations.

(C) 2020 by the authors. Licensee MDPI, Basel, Switzerland. This article is an open access article distributed under the terms and conditions of the Creative Commons Attribution (CC BY) license (http://creativecommons.org/licenses/by/4.0/). 